\title{
Supervisors' Views on Employer Responsibility in the Return to Work Process. A Focus Group Study
}

\author{
Kristina Holmgren • Synneve Dahlin Ivanoff
}

Published online: 13 March 2007

(C) Springer Science+Business Media, LLC 2007

Erratum to: Journal of Occupational Rehabilitation, DOI: 10.1007/s10926-006-9041-4

In the above mentioned article, the second author Synneve Dahlin Ivanoff's last name (her surname) is wrong. Her first name is Synneve and her last name is a double name: Dahlin Ivanoff. Thus, the correct reference should read: Holmgren K, Dahlin Ivanoff S.

The online version of the original article can be found at: http://dx.doi.org/10.1007/s10926-006-9041-4 